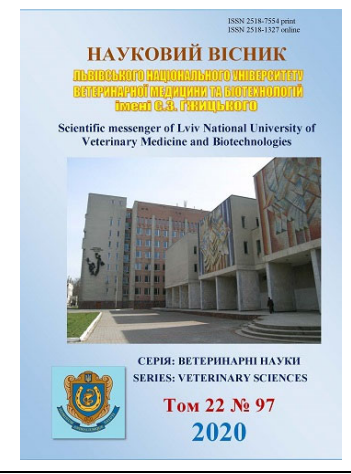

\author{
Науковий вісник Дьвівського національного університету \\ ветеринарної медицини та біотехнологій імені С.3. Гжицького. \\ Серія: Ветеринарні науки \\ Scientific Messenger of Lviv National University \\ of Veterinary Medicine and Biotechnologies. \\ Series: Veterinary sciences
}

UDC 631.8:638.19

\title{
Sensitivity of bees' pathogenic bacteria to a sample of copper solution and silver citrate
}

O. Ye. Galatiuk, T. A. Romanishina, A. R. Lakhman

Zhytomyr National Agroecological University, Zhytomyr, Ukraine

Article info

Received 07.02.2020

Received in revised form 09.03 .2020

Accepted 10.03.2020

Zhytomyr National Agroecological University, Stary Boulevard, 7, Zhytomyr, 10008, Ukraine Tel.: +38-067-971-04-63 E-mail: olekhalatyuk@gmail.com
Galatiuk, O. Ye., Romanishina, T. A., \& Lakhman, A. R. (2020). Sensitivity of bees' pathogenic bacteria to a sample of copper solution and silver citrate. Scientific Messenger of Lviv National University of Veterinary Medicine and Biotechnologies. Series: Veterinary sciences, 22(97), 106111. doi: $10.32718 /$ nvlvet9717

The article presents the studies' results of the experimental disinfectan's antimicrobial effect on microorganisms of various morphological groups that currently cause bees' enterobacteriosis. For work, we used cultures of bee enterobacteria: a pure microorganisms culture of the species Klebsiella pneumoniae and natural (mixed) strains of enterobacteria excreted from sick bee colonies at apiaries in the North-Western region of Ukraine. Sick bees' families had similar clinical signs - the abdomen in sick bees was thickened, filled with fecal matter, the bees moved slowly, noted damage to the pupae among the sealed brood in the spring and summer, and the families took off in August-September. A solution of copper and silver citrate was used in the native state and in such concentrations - 1:2, 1:5, 1:10, diluted in sterile $0.9 \%$ $\mathrm{NaCl}$. The studies were conducted by the disk-diffuse method. The most active influence of a copper and silver citrate solution sample was recorded with native use on both studied cultures, and the enlightenment zone in the mixed culture was significantly greater (by $28.8 \%$ ) than in the pure culture of the species Klebsiella pneumoniae. A significant difference was noted between the two cultures of microorganisms (pure and mixed) with similar dilutions (1:2 and 1:10). Due to the presence of genes encoding adhesins, they determine the formation of a biofilm on the surface of the medium during cultivation of the studied microorganisms, we have a pronounced bacteriostatic effect of the native sample. Such changes are explained by the antimicrobial action of AgNPs associated with the mechanisms of AgNPs adhesion to the surface of the cell wall and membrane, penetration of AgNPs into the cell and damage to intracellular structures (mitochondria, vacuole, ribosomes) and biomolecules (proteins, lipids and DNA), induction of cellular toxicity and oxidative stress AgNPs caused by the generation of reactive oxygen species (ROS) and free radicals and modulation of the signal transduction pathways, which is part of the experimental sample. Silver nanoparticles, unlike copper, can be easily synthesized using physical, chemical, electrochemical and biological methods. Therefore, there is a growing demand for the development of effective and environmentally friendly disinfectants in beekeeping. Further research will be aimed at evaluation a toxic dose of LD50 AgNPs in bee gardens, followed by studying the effect of certain doses in hives in vivo, probably not only as an organic disinfectant, but also as an immunomodulator that stimulates the bee's body, helps to suppress the development of pathogenic microorganisms in the hive.

Key words: silver $(A g N P S)$ and copper nanoparticles, mixed culture, pure culture, Klebsiella pneumoniae, bactericidal and bacteriostatic effect, disco-diffusion method.

\section{Чутливість хвороботворних бактерій бджіл до зразка розчину міді i цитрату срібла}

О. Є. Галатюк, Т. О. Романишина, А. Р. Лахман

Житомирський національний агроекологічний університет університет, м. Житомир, Украӥна 
У статті наведено результати досліджень антимікробної дії експериментального дезінфектану до мікроорганізмів різних морфологічних груп, які в даний час зумовлюють ентеробактеріози у бджіл. Для роботи були використані культури ентеробактерій бджіл: чиста культура мікроорганізмів виду Klebsiella Pпеитопіае та природні (змішані) шттами ентеробактерій, виділені від хворих бджолиних сімей з пасік Північно-Західного регіону України. Хворі бджолині сім $\dddot{\imath}$ мали подібні клінічні ознаки - черевце у хворих бджіл - потовщене, заповнене фекальними масами, бджоли повільно рухалися, виявляли ураження лялечок серед запечатаного розплоду у весняно-літній період, злітання сімей у серпні-вересні. Розчин цитрату міді і иитрату срібла застосовували в нативному стані і в таких концентраціях - 1:2, 1:5, 1:10, розведених на стерильному 0,9\% NaCl. Дослідження проводилися дискодифузійним методом. Найбільш активний вплив зразка розчину цитрату міді та цитрату срібла реєструвався при нативному застосуванні на обидві досліджувані культури, причому зона просвітлення у змішаній культурі була достовірно більшою (на 28,8\%), ніж у чистій культурі виду Klebsiella Рпештопіае. Відмічена достовірна різниця між двома культурами мікроорганізмів (чистою та змішаною) при аналогічних розведеннях (1:2 i 1:10). Завдяки наявності генів, які кодують адгезини і зумовлюють формування біоплівки на поверхні середовища при культивуванні досліджуваних мікроорганізмів, яскраво виражена бактеріостатична дія нативного зразка. Такі зміни пояснюємо антимікробною дією AgNPs, пов'язаною з механізмами адгезії АgNPs до поверхні клітинної стінки і мембрани, проникненням AgNPs всередину клітини та пошкодженням внутрішньоклітинних структур (мітохондрій, вакуоль, рибосом) і біомолекул (білків, ліпідів і ДНК), індукуванням AgNPs клітинної токсичності і окислювального стресу, викликаного генерацією реактивних форм кисню (РФК) і вільних радикалів та модуляцією сигнальних шляхів трансдукиії, щзо входить до складу експериментального зразка. Наночастки срібла, на відміну від міді, можуть бути легко синтезовані за допомогою фізичних, хімічних, електрохімічних та біологічних методів. Тому зростає попит на розробку ефективних та екологічно безпечних дезінфектантів у бджільництві. Подальші дослідження будуть спрямовані на встановлення токсичної дози LD5о AgNPs у садках бджіл з подальшим вивченням впливу певних доз у вуликах іп vіvо, щзо ймовірно проявить себе не тільки як органічний дезінфектант, а і як імуномодулятор, котрий стимулює організм бджоли, щуо сприяє пригніченню розвитку патогенних мікроорганізмів у вулику.

Ключові слова: наночастинки срібла (AgNPs) та міді, змішана культура, чиста культура, Klebsiella Pneuтопіае, бактерицидна та бактеріостатична дія, диско-дифузійний метод.

\section{Вступ}

Однією з проблем в Україні та у світі є масова загибель бджіл у зимово-веснятий період. Колапс бджолиних сімей проявляється масово при наявності таких важливих факторів: порушення рівноваги умовнопатогенної мікрофлори кишечнику бджіл; поширення збудників у вулику та на пасіці в результаті зниження резистентності у частини бджолосімей сімей; дія сублетальних доз пестицидів тощо (Cox-Foster et al., 2007; Glenny et al., 2017). Основними клінічними ознаками, які свідчать про підвищення концентрації бактерій в організмі бджіл, є поява різкого проносу, зниження продуктивності та загальна слабкість бджолиної сім’ї (Cox-Foster et al., 2007; Evans \& Schwarz, 2011; Runckel et al., 2011). Згідно з працями іноземних та вітчизняних авторів, бактеріальні хвороби бджіл набирають все більшого поширення на пасіках деяких країн Європи, України та Америки (Pal et al., 2007; Runckel et al., 2011; Santo Pereira et al., 2016; Glenny et al., 2017; Serdyuchenko, 2017; Galatyuk et al., 2020), що завдає бджільництву значних економічних збитків.

Дезінфікуючі та пробіотичні засоби є альтернативою антибіотикам, використання останніх у бджільництві заборонено. Удосконалення профілактичних заходів за колапсу бджолиних сімей є ключем до підвищення рентабельності будь-якого пасічного господарства (Balasubramanian et al., 2017). Ринок препаратів для лікування та запобігання ентеробактеріозам бджіл дуже вузький. Тому оцінка ефективності нових сучасних препаратів для оздоровлення бджіл є важливою сходинкою в організації профілактичних заходів не лише в Україні, а й у світі (Rai et al., 2014; Tran et al., 2018; Galatyuk et al., 2020).

В даний час актуальним питанням є вивчення вітчизняних антимікробних препаратів, які ефективно діяли б на грампозитивну та грамнегативну мікрофлору вулика.
Метою нашої роботи було визначити активність експериментального дезінфектанту (розчину цитрату міді і цитрату срібла), щодо чистої культури виду Klebsiella Pneumoniae, природніх (змішаних) штамів ентеробактерій бджіл in vitro.

\section{Матеріал і методи досліджень}

Для роботи були використані культури ентеробактерій бджіл: чиста культура виду Klebsiella Pneumoniae. Даний штам виділений та ідентифікований на базі науково-дослідної лабораторії кафедри мікробіології, фармакології та епізоотології факультету ветеринарної медицини Житомирського національного агроекологічного університету (ЖНАЕУ) та Державної установи “Житомирський обласний лабораторний центр Міністерства охорони здоров'я України" у 2018-2019 pр; змішана культура - виділена від хворих бджолиних сімей $з$ пасік Північно-Західного регіону України, які мали мали подібні клінічні ознаки - черевце у хворих бджіл - потовщене, заповнене фекальними масами, бджоли повільно рухалися, виявляли ураження лялечок серед запечатаного розплоду у весняно-літній період, злітання сімей у серпнівересні. Культури зберігаються у холодильнику за $\mathrm{t}$ 5-7 ${ }^{\circ} \mathrm{C}$ і пересіваються методом штриха на скошений агар у пробірки з інтервалом в 30 діб на середовище МПА (м'ясо-пептонний агар).

Вивчення тинкторіально-морфологічних ознак проводили мікроскопічними дослідженнями (збільшення мікроскопа $\times 1000)$. Препарати фарбували методом Грама (Pul'cherovskaya et al., 2017).

Розчин цитрату міді і цитрату срібла був наданий нам ТОВ “СГП” МБС м. Києва. Дезінфектант застосовували в нативному стані й у таких концентраціях $1: 2,1: 5,1: 10$, розведених на стерильному $0,9 \% \mathrm{NaCl}$. Дослідження проводилися диско-дифузійним методом 
(Galatyuk et al., 2020) на семи чашках Петрі для кожної культури, за якими спостерігали три доби.

\section{Результати та їх обговорення}

Препарати, які містять сполуки срібла та перешкоджають і пригнічують ріст та розвиток бактерій, використовувались як протимікробний засіб $з$ давніх часів (Dakal et al., 2016). У гуманній медицині досліджено, що наночастинки срібла мають підвищений антибактеріальний потенціал щодо E. coli i $S$. aureus, тому вважаються придатними для використання у хірургії (Graves et al., 2015). Крім того, $\mathrm{Ag}^{+}$активно пригнічує утворення біоплівок in vitro $\mathrm{i}$ мінімізує зростання інших патогенних мікроорганізмів (Tran et al., 2013; 2018). На теперішній час для успішної діагностики, лікування та профілактики інфекційних захворювань основною перешкодою стала мультирезистентність патогенних мікроорганізмів до протимікробних препаратів. Тому велику увагу привернуло використання наночасток срібла (AgNPs) як потужного антибактеріального засобу. AgNPs володіють такими фізико-хімічними параметрами, які впливають на активність мікробного потенціалу: розмір, форму, поверхневий заряд, концентрацію і колоїдний стан. Адгезія AgNPs до мікробних клітин, проникнення всередину клітин, генерація вільних радикалів, а також модуляція шляхів трансдукції мікробного сигналу є найбільш вираженими способами прояву бактерицидної дії наночасток срібла (Dakal et al., 2016). Тому теоретично перспективним $є$ використання лікарських засобів та дезінфектантів, які місять у своєму складі іони срібла.

У профілактиці ентеробактеріозів бджіл важливе значення має попереднє визначення активності характеру дії нових препаратів in vitro перед апробацією на пасіках. Мікроорганізми різних морфологічних груп відрізняються стійкістю до одного й того ж препарату, про що свідчать різні діаметри зон бактерицидної та бактеріостатичної дій (рис. 1, рис. 2).

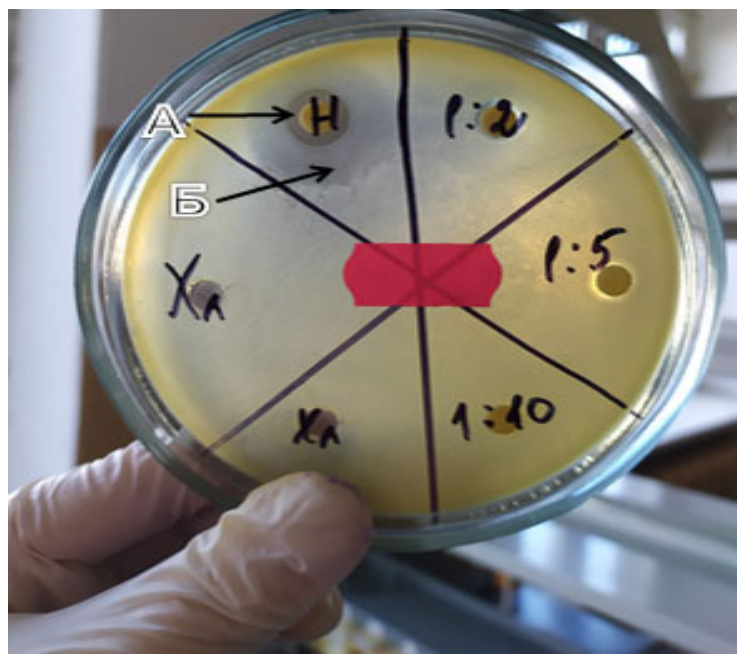

Рис. 1. Візуальні зміни при бактеріологічних дослідженнях активності зразка розчину цитрату міді та цитрату срібла на чисту культуру виду Klebsiella Pneumoniae (24 год): А - бактерицидна дія; Б - бактеріостатична дія

Відомо, що бактерії виду Klebsiella Pneumoniae містять капсульні гени, асоційовані з мукополісахаридами (HMV-гіпермуковіскозний фенотип) i здатні поглинати позитивно заряджені іони $\mathrm{Ag}^{+} \mathrm{i} \mathrm{Cu}^{+}-\mathrm{cпе}-$ цифічні детермінанти вірулентності (рис. 1). Крім того, слизова капсула ентеробактерій виду Klebsiella Pneumoniae слугує не так захисною оболонкою, як одним із факторів “притягування" катіонів металів аніонними залишками сіалової кислоти (Santo Pereira et al., 2016).

Найактивніший вплив зразка розчину цитрату міді та цитрату срібла реєструвався при нативному застосуванні на обидві досліджувані культури, причому зона просвітлення у змішаній культурі була достовірно більшою (на 28,8 \%), ніж у чистій культурі виду Klebsiella Pneumoniae. Відмічена достовірна різниця між двома культурами мікроорганізмів (чистою та змішаною) при аналогічних розведеннях у концентраціях 1:2 і 1:10 (табл. 1).

\section{Таблиця 1}

Дія зразка розчину цитрату міді та цитрату срібла на мікроорганізми бджіл in vitro $(\mathrm{n}=7)$

\begin{tabular}{ccccccccc}
\cline { 2 - 8 } & \multicolumn{4}{c}{ Чиста культура виду Klebsiella } & & \multicolumn{2}{c}{ 3мімана культура } \\
\cline { 2 - 9 } & Нативний & $1: 2$ & $1: 5$ & $1: 10$ & Нативний & $1: 2$ & $1: 5$ & $1: 10$ \\
\hline $\begin{array}{c}\text { Зона затримки } \\
\text { росту, мм, } \\
\text { M } \pm \text { m }\end{array}$ & $14,14 \pm 0,35$ & $11,14 \pm 0,45$ & $9,85 \pm 0,45$ & - & $19,86 \pm 0,45^{* *}$ & $13,86 \pm 0,35^{*}$ & $9,43 \pm 0,39$ & $8,57 \pm 0,27^{* *}$ \\
\hline
\end{tabular}

Примітка: * - $\mathrm{P}<0,05 ; * *-\mathrm{P}<0,01$ порівняно 3 зонами просвітлення у біоплівці чистої культури виду Klebsiella Pneuтопiаe при аналогічних розведеннях

Завдяки наявності генів, які кодують адгезини i зумовлюють формування біоплівки на поверхні середовища при культивуванні досліджуваних мікроорганізмів, яскраво виражена бактеріостатична дія нативного зразка (рис. 1 - Б). Такі зміни пояснюємо антимікробною дією AgNPs, пов'язаною 3 механізмами адгезії AgNPs до поверхні клітинної стінки і мембрани, проникненням AgNPs всередину клітини та пошкодженням внутрішньоклітинних структур (мітохондрій, вакуоль, рибосом) і біомолекул (білків, ліпідів і ДНК), індукуванням AgNPs клітинної токсичності й окислювального стресу, викликаного генерацією реа- 
ктивних форм кисню (РФК) і вільних радикалів та модуляцією сигнальних шляхів трансдукції, що входить до складу експериментального зразка (Dakal et al., 2016).

Встановлено, що в шлунково-кишковому тракті здорової медоносної бджоли можуть бути різні мікроорганізми, що належать до родів: Bacillus, Clostridium, Pseudomonas, Bacterium, Chromobacterium, Pseudobacterium, Lactobacterium, Mycobacterium, Actinomycetes, Proactinomycetes, Streptococcus, Micrococcus (Terekhov \& Serdyuchenko, 2016). Видовий склад мікрофлори кишечника у бджіл на початку та після зимівлі різко обмежений і представлений в основному бактеріями групи кишкової палички, стафілококами, псевдомонадами і дріжджоподібними грибами (Serdyuchenko,
2017). Для практичного підтвердження цього факту вивчили тинкторіально-морфологічні властивості мікробного пейзажу на зоні бактеріостатичної дії дезінфектанту (рис. 2 - А) та 3 різних ділянок біоплівки накопичувальної культури (рис. 2 - Б). У мікроскопічних препаратах з бактеріостатичної зони у полі зору мікроскопа спостерігали наявність переважно грамнегативних паличок різного розміру, розміщених поодиноко і у вигляді скупчень, які, ймовірно, належать до родини Enterobacteriaceae (рис. 2 - А). Мікробний пейзаж поверхні біоплівки без дифузного інгібування препарату відрізнявся наявністю грамнегативних та грампозитивних штамів бактерій (рис. 2 Б), тому і різною сприйнятливістю мікроорганізмів до діючих речовин досліджуваного дезінфектанту.

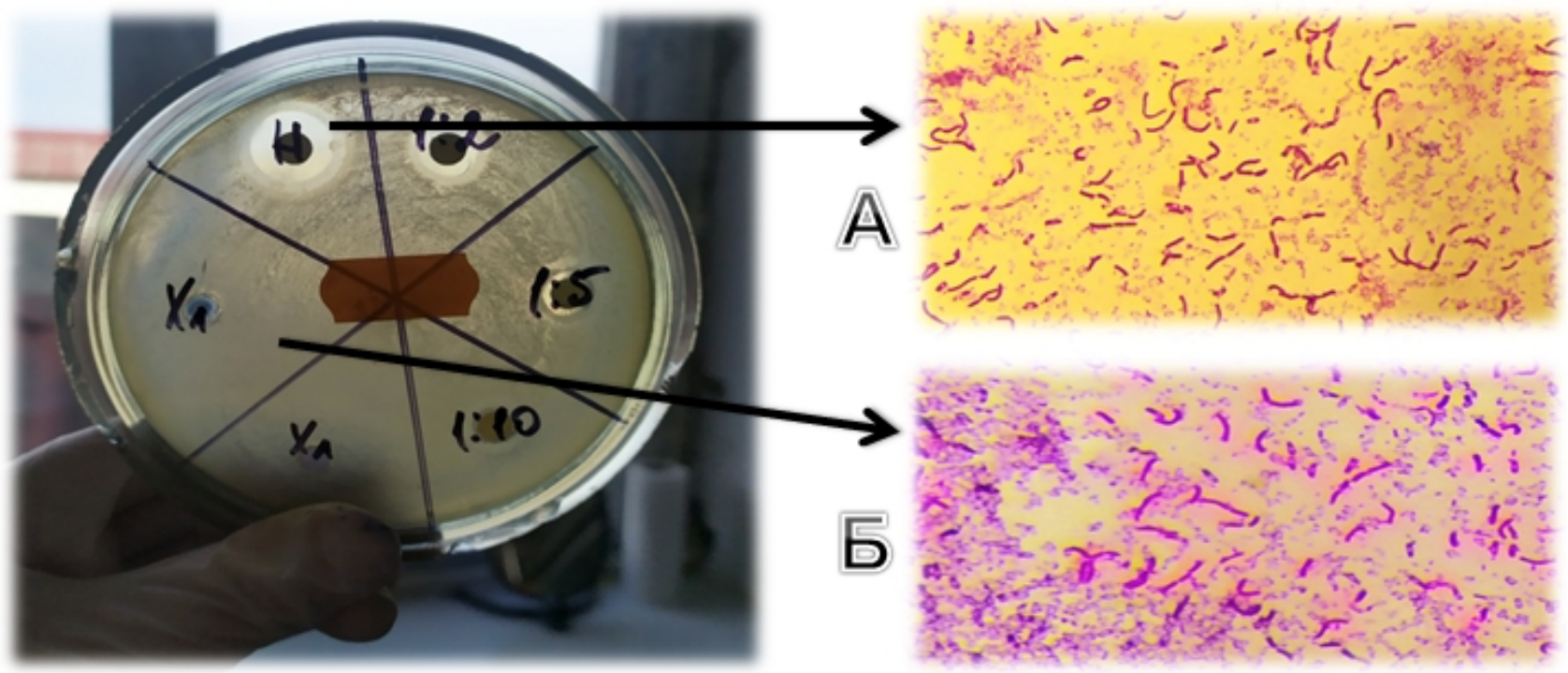

Рис. 2. Дія зразка розчину цитрату міді та цитрату срібла на змішану культуру (24 год) міроорганізмів уражених бджолосімей : А - мікроскопія колоній мікроорганізмів на зоні бактеріостатичної дії дезінфектанту (метод Грама (збільшення $\times 1000)$ ); Б - мікроскопія колоній мікроорганізмів біоплівки (метод Грама (збільшення $\times 1000)$ )

Важливою фізико-хімічною властивістю $\mathrm{AgNPs} \epsilon$ ïx розмір. Загалом для того, щоб наночастинки були ефективними, їхній розмір не повинен перевищувати 50 нм. Наночастинки срібла розміром від 10 до 15 нм володіють підвищеною стабільністю, біосумістністю і підвищеною антимікробною активністю (Yacaman et al., 2001). Антибактеріальна дія AgNPs на грамнегативні бактерії зумовлена тим, що частинки такого розміру мають високу проникаючу здатність в клітини бактерій (Morones et al., 2005). Деякі дослідження показали, що наночастинки AgNPs діаметром менше ніж 30 нм ефективніші проти $S$. aureus і $K$. pneumoniae (Collins et al., 2010), а наночастинки AgNPs розміром 5-10 нм проявляють як бактеріостатичний, так і бактерицидний ефект проти $S$. aureus, MSSA i $M R S A$. Цікаво, що прикріплення AgNPs до клітинних мембран і пов'язані з цим зміни ліпідного бішару призводять до підвищення проникності мембрани, пошкодження та загибелі клітин, виявляють потужний антибактеріальний ефект, що здається більш вираженим при використанні наночастинок меншого розміру (Dakal et al., 2016).

Для адгезії позитивний поверхневий заряд AgNPs має вирішальне значення. Він забезпечує електростатичне тяжіння між негативно зарядженою клітинною мембраною мікроорганізмів та AgNPs, тим самим полегшуючи адгезію AgNPs до клітинних мембран. Морфологічні зміни у бактеріальних клітинах характеризуються підвищенням квоти (порогу) тиску цитоплазми та відшаруванням цитоплазматичної мембрани, що призводить до остаточного розриву клітинної стінки. Оскільки в клітинній стінці присутні сірковмісні білки, взаємодія AgNPs з ними зумовлює незворотні деструктивні зміни в структурі клітинної стінки (Dakal et al., 2016). У мікробних клітинн, які зазнали впливу AgNPs, інгібується низка життєво важливих функцій, виникають генетичні зміни - конденсація генетичного матеріалу, що в кінцевому підсумку призводить до клітинного некрозу (Rai et al., 2014).

Клітинна стінка грампозитивних бактерій складається 3 негативно зарядженого шару пептидоглікану 
(товщина 30 нм), його кількість порівняно більша у грампозитивних бактерій, ніж у грамнегативних (товщина 3-4 нм) (Rai et al., 2014). 3 цієї причини товста клітинна стінка і велика кількістю молекул пептидоглікану грампозитивних бактерії протидіють іонам срібла і роблять бактерію порівняно стійкою до впливy AgNPs (Dakal et al., 2016). Навпаки, грамнегативні бактерії більш сприйнятливі до препаратів на основі AgNPs завдяки меншій товщині клітинної стінки i меншій кількості пептидоглікану (Rai et al., 2014).

Проникаючи всередину мікробної клітини, AgNPs взаємодіє з білками, ліпідами і ДНК. Порушення синтезу білка передбачає денатурацію рибосом, що призводить до гальмування трансляції (Rai et al., 2014; Dakal et al., 2016). Взаємодія AgNPs з ДНК призводить до зсуву або денатурації ДНК (Kumar et al., 2014). Відомо, що головним регулятором вірулентності у $S$. aureus є двокомпонентна система (TCS), яка визначає квоту (Agr) (Rai et al., 2014; Balasubramanian et al., 2017). S. aureus продукує базальні рівні сигнальної молекули пептиду - автоіндукуючий пептид (AIP). Накопичення AIP викликає активізацію експреciї локусу agr, який складається 3 двох промоторів P2 і P3, що кодують AgrBDCA і головний регулятор PHК-ефектора (RNAIII). 3 підвищенням щільності бактеріальної клітини до певного кворуму накопичений АІП зв'язується 3 гістидинкіназою (AgrC), яка фосфорилює регулятор реакції AgrA. Активована AgrA регулює гени вірулентності, індукуючи власний промотор Р2 для збільшення транскрипції AgrBDCA та сусідній промотор Р3 для керування транскрипцією RNAIII (Balasubramanian et al., 2017). Останні два гена в опероні AgrP2, AgrD та AgrB кодують пропептид AIP та трансмембранну ендопептидазу, що бере участь у переробці та експорті зрілого білкового продукту. RNAIII - ключова ефекторна молекула, яка зв'язує ген AgrTCS, зумовлюючи вірулентність. Це молекула РНК, яка зв'язується 3 п'ятою ділянкою цільових мРНК і посттранскрипційно пригнічує або активує фактори вірулентності (Balasubramanian et al. 2017). Ймовірно, AgNPs, проникаючи в бактеріальну клітину, порушує активацію сигнальних локусів в реакціях транскрипції та усуває генетичну здатність до вірулентності.

AgNPs мають також антибактеріальний потенціал, пов'язаний з генерацією вільних радикалів і реактивних форм кисню (РФК), що підвищує окисний стрес в клітинах. Іони Ag (+) зв'язуються 3 клітинною мембраною мікробів, рецептори якої передають сигнали до мітохондрій і блокують дихальну функцію мікроорганізмів, викликаючи токсичний ефект (дисфункція дихального ланцюга). Надмірна кількість вільних радикалів викликає пряме пошкодження мембрани мітохондрій, що призводить до їх некрозу (Dakal et al., 2016).

AgNPs впливають на бактеріальну сигнальну трансдукцію (сигнальні шляхи, які впливають на ріст бактерій та інші молекулярні і клітинні активності). Наночастинки срібла інгібують фосфорилювання білків шляхом гальмування їхньої ферментативної активності. Ймовірно, ріст бактерій у досліджуваній змішаній культурі на межі бактеріостатичної та бактерицидних зон був пригнічений, оскільки фосфорилювання білка тирозином залучено в біосинтез і транспорт екзополісахариду та капсульного полісахариду у ряді грампозитивних i грамнегативних бактерій (рис. 2). AgNPs модулюють клітинну сигналізацію, що дефосфорилюється залишками тирозину на ключових бактеріальних пептидних субстратах і тим самим інгібується ріст мікроорганізмів (Dakal et al., 2016).

На нашу думку, інгібування утворення біоплівок і мінімізація шансів патогенного зростання як грамнегативних, так і грампозитивних мікроорганізмів in vitro відбулося саме завдяки дії катіонів срібла, які мають однакову площу поверхні, але різну форму, i тому проявляють диференціальну бактерицидну активність, що може бути пов'язано з варіаціями ефективних площ поверхні й активних граней AgNPs (Tran et al., 2018). Порівняно зі сферичними або стрижневими AgNPs, усічені AgNPs трикутної форми виявляють підвищену антибактеріальну дію (Pal et al., 2007), на відміну від катіонів міді, які через будову атомів (важкий метал) нездатні до широкого спектру модуляції iii наночастинок, що своєю чергою перешкоджає проникненню їх у бактеріальні клітини, особливо багатих на пептидоглікан (грампозитивні мікроорганізми).

\section{Висновки}

1. Досліджуваний нативний розчин цитрата срібла і міді у ролі дезінфектанту активніше проявив антибактеріальну дію щодо змішаної культури. Бактеріостатичний ефект зразка розчину міді та цитрату срібла краще виражений щодо чистої культури мікроорганізмів виду Klebsiella Pneumoniae.

2. Для ефективної дії дезінфектантів, які містять у своєму складі AgNPs, необхідний синтез наночастинок відповідного розміру і форми з бажаними поверхневими властивостями для дії на мікроорганізми різних морфологічних груп.

3. Наночастки срібла, на відміну від міді, можуть бути легко синтезовані за допомогою фізичних, хімічних, електрохімічних та біологічних методів. Тому зростає попит на розробку рентабельних та екологічно безпечних дезінфектантів у бджільництві з використання чистих наначасточок цитрату срібла.

Подальші дослідження будуть спрямовані на встановлення токсичної дози LD50 AgNPs у садках бджіл з подальшим вивченням впливу певних доз у вуликах in vivo, що, ймовірно, проявить себе не тільки як органічний дезінфектант, а і як імуномодулятор, котрий стимулює організм бджоли, що сприяє підвищенню резистентності бджолиної сім'ї та пригніченню розвитку патогенних мікроорганізмів у вулику.

\section{References}

Balasubramanian, D., Harper, L., Shopsin, B., \& Torres, V. J. (2017). Staphylococcus aureus pathogenesis in 
diverse host environments. Pathogens and disease, 75(1), 1-13. doi: 10.1093/femspd/ftx005.

Collins, T. L., Markus, E. A., Hassett, D. J., Robinson, J. B. (2010). The effect of a cationicporphyrinon Pseudomonas aeruginosa biofilms. Curr. Microbiol., 61, 411-416. doi: 10.1007/s00284-010-9629-y.

Cox-Foster, D. L., Conlan, S., Holmes, E. C., Palacios, G., Evans, J. D., Moran, N. A., Quan, P. L., Briese, T., Hornig, M., Geiser, D. M., Martinson, V., vanEngelsdorp, D., Kalkstein, A. L., Drysdale, A., Hui, J., Zhai, J., Cui, L., Hutchison, S. K., Simons, J. F., Egholm, M., Pettis, J. S. \& Lipkin, W. I. (2007). A metagenomic survey of microbes in honey bee colony collapse disorder. Science, 318, 283-287. doi: 10.1126/science. 1146498 .

Dakal, T. C., Kumar, A., Majumdar, R. S., \& Yadav, V. (2016). Mechanistic basis of antimicrobial actions of silver nanoparticles. Frontiers in microbiology, 7, 1831. doi: 10.3389/fmicb.2016.018310.

Evans, J. D., \& Schwarz, R. S. (2011). Bees brought to their knees: microbes affecting honey bee health. Trends in microbiology, 19(12), 614-620. doi: 10.1016/j.tim.2011.09.003.

Galatyuk, O., Romanishina, T., Lakhman, A., Lysenko, O., \& Shimanska, V. (2020). Stiykist' patohennykh enterobakteriy bdzhil do eksperymental'noho yodovmisnoho dezinfektantu "Yodis Dez №2". Naukovi horyzonty. 1(86), 71-78. doi: 10.33249/2663-21442020-86-1-71-78 (in Ukrainian).

Glenny, W., Cavigli, I., Daughenbaugh, K. F., Radford, R., Kegley, S. E., \& Flenniken, M. L. (2017). Honey bee (Apis mellifera) colony health and pathogen composition in migratory beekeeping operations involved in California almond pollination. PloS one, 12(8), e0182814. doi: 10.1371/journal.pone.0182814.

Graves, J. L., Tajkarimi, M., Cunningham, Q., Campbell, A., Nonga, H., \& Harrison, S. H. (2015). Rapid evolution of silver nanoparticle resistance in Escherichiacoli. Front. Genet., 6, 42. doi: 10.3389/fgene.2015.00042.

Kumar, S., Singh, M., Halder, D., \& Mitra, A. (2014). Mechanistic study of antibacterial activity of biologicaly synthe sized silver nanocolloids. Colloids Surfaces, 449, 82-86. doi: 10.1016/j.colsurfa.2014.02.027.

Morones, J. R., Elechiguerra, J. L., Camacho, A., Holt, K., Kouri, J. B., \& Ramírez, J. T. (2005). The bactericidal effect of silver nanoparticles. Nanotechnology, 16, 2346-2353. doi: 10.1088/09574484/16/10/059.

Pal, S., Tak, Y. K., \& Song, J. M. (2007). Does the antibacterial activity of silver nanoparticles depend on the shape of the nanoparticle? A study of the gramnegative bacterium Escherichia coli. Appl. Environ. Microbiol., 27, 1712-1720. doi: 10.1128/AEM.0221806.

Pulcherovskaya, L. P., Vasilev, D. A., \& Zolotuhin, S. N. (2017). Vyidelenie bakteriy roda Citrobacter. Vestnik Ulyanovskoy gosudarstvennoy selskohozyaystvennoy akademii, 3(39), 83-87. doi: 10.18286/1816-45012017-3-83-87 (in Russian).

Rai, M., Kon, K., Ingle, A., Duran, N., Galdiero,S., \& Galdiero, M. (2014). Broad spectrum bioactivities of silver nanoparticles:the emergingtrends and future prospects. Appl. Microbiol. Biotechnol., 98, 19511961. doi:10.1007/s00253-013-5473-x.

Runckel, C., Flenniken, M. L., Engel, J. C., Ruby, J. G., Ganem, D., Andino, R. \& DeRisi, J. L. (2011). Temporal analysis of the honey bee microbiome reveals four novel viruses and seasonal prevalence of known viruses, Nosema, and Crithidia. PLoS One, 6. doi: 10.1371/journal.pone.0020656.

Santo Pereira, R., Dias, V. C., Ferreira-Machado, A. B., Resende, J. A., Bastos, A. N., Bastos, L. Q., \& Diniz, C. G. (2016). Physiological and molecular characteristics of carbapenem resistance in Klebsiella pneumoniae and Enterobacter aerogenes. The Journal of Infection in Developing Countries, 10(06), 592-599. doi: $10.3855 /$ jidc. 6821.

Serdyuchenko, I. V. (2017). Kolichestvennaya otsenka mikroflory pishchevaritel'nogo trakta pchel do i posle zimovki. Molodoy uchenyy, 2, 286-289 (in Russian).

Terekhov, V. I., \& Serdyuchenko, I. V. (2016). Bakterii roda Escherichia (analiticheskiy obzor). Vestnik veterinarii, 2(77), 35-42 (in Russian).

Tran, Q. H., Nguyenm, V. Q., \& Le, A. T. (2013). Silvernanoparticles: synthesis, properties, toxicology, applications and perspectives. Adv. Nat. Sci. Nanosci. Nanotechnol., 4, 1-13. doi: 10.1088/2043-6262/4/3/ 033001

Tran, Q. H., Nguyen, V. Q., Le Anh-T. (2018). Silver nanoparticles: synthesis, properties, toxicology, applications and perspectives. Adv. Nat. Sci: Nanosci. Nanotechnol., 9, 1-23. doi: 10.1088/2043-6254/aad12b.

Yacaman, M. J., Ascencio, J. A., Liu, H. B., \& GardeaTorresdey, J. (2001). Structure shape and stability of nanometric sized particles. J. Vacuum Sci. Technol. B. Microelectron. Nanometer. Struct., 19, 1091-1103. doi: $10.1116 / 1.1387089$. 